\title{
Synthesis and characterization of novel thiosemicarbazone palladacycles ${ }^{\dagger}$
}

\author{
Marcos Rúa-Sueiro*, Paula Munín-Cruz, Francisco Reigosa, José M. Vila and M. Teresa Pereira \\ Affiliation: Department of Inorganic Chemistry, Faculty of Chemistry, University of Santiago de Compostela, \\ Avda. das Ciencias s/n, 15782, Santiago de Compostela, Spain. \\ * Correspondence: marcos.rua@rai.usc.es \\ + Presented at the title: Synthesis and characterization of novel thiosemicarbazone palladacycles, Place: The \\ 23rd International Electronic Conference on Synthetic Organic Chemistry, Date: Nov. 15th 2019.
}

Received: Nov. 6th 2019; Accepted: date; Published: Nov. 15th 2019

\begin{abstract}
:
Since the appearance of the term palladacycle, as coined by Trofimenko[1], one of the most salient groups is the one comprising thiosemicarbazones.

Herein, the synthesis and characterization of several palladium cyclometallated compounds with thiosemicarbazone ligands is discussed. The ligands were synthesized by treatment of a ketone with four different thiosemicarbazides in acidified aqueous solution. Then, they were conveniently treated with a palladium salt to yield the corresponding palladacycle. All show a tetranuclear structure with $[\mathrm{C}, \mathrm{N}, \mathrm{S}]$ coordination of the ligands to the metal centers.
\end{abstract}

Keywords:

Cyclometallated, thiosemicarbazones, palladium

\section{Introduction}

Over the years, ligands such as thiosemicarbazones have been studied in cyclometallation reactions[2]. The main reason being they possess many donor atoms that can coordinate to the metal. Their applications have been widely studied; these compounds have catalytic properties in crosscoupling reactions[3,4].

They may also be used as cytotoxic and antitumoral species applicable in biological assays[5,6,7].

\section{Experimental}

\subsection{Ligands}

In an Erlenmeyer flask the thiosemicarbazide and hydrochloric acid $(0,4 \mathrm{~cm} 3)$ were added in water $(20 \mathrm{~cm} 3)$. After which the ketone was added. The mixture was stirred at room temperature for $8 \mathrm{~h}$, after which a solid appeared, that was filtered, washed with water and dried under vacuum. 
<smiles>COc1ccc(C(C)=O)cc1</smiles>

$R=H, M e, E t, P h$<smiles>[R]NC(=S)N/N=C(\C)c1ccc(OC)cc1</smiles>

1a-4a

Scheme 1. Synthesized ligands

\begin{tabular}{ccccc}
\hline Ligand & $\mathrm{R}$ & Thiosemicarbazide $(\mathrm{mg})$ & Ketone $(\mathrm{mg})$ & Efficiency $(\%)$ \\
\hline 1a & $\mathrm{H}$ & 250 & 412 & 90 \\
2a & $\mathrm{Me}$ & 250 & 357 & 98 \\
3a & $\mathrm{Et}$ & 250 & 315 & 88 \\
$4 \mathrm{a}$ & $\mathrm{Ph}$ & 250 & 225 & 87 \\
\hline
\end{tabular}

Chart 1. Quantities of reagents added

\subsection{Palladacycles}

In a Radley's tube potassium tetrachloropalladate was added in distilled water $\left(6 \mathrm{~cm}^{3}\right)$. Then the thiosemicarbazone ligand was added in ethanol $\left(40 \mathrm{~cm}^{3}\right)$. The resulting solution was stirred for 24 hours at room temperature. A suspension formed was centrifugated and the solid was dried under vacuum.<smiles>[R]NC(=S)N/N=C(\C)c1ccc(OC)cc1</smiles>

$1 a-4 a$

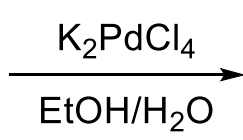

$R=H, M e, E t, P h$

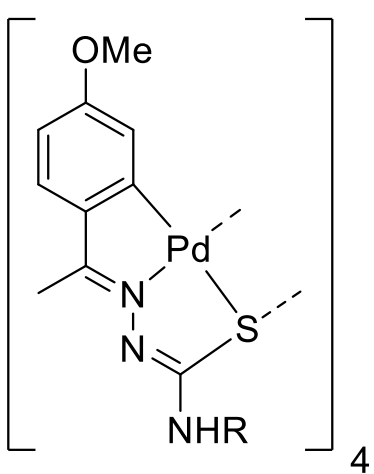

$1 b-4 b$

Scheme 2. Cyclometallated compounds synthesized

\begin{tabular}{ccccc}
\hline Compound & $\mathrm{R}$ & $\mathrm{K}_{2} \mathrm{PdCl}_{4}(\mathrm{mg})$ & Thiosemicarbazone $(\mathrm{mg})$ & Efficiency $(\%)$ \\
\hline $1 \mathrm{~b}$ & $\mathrm{H}$ & 200 & 164 & 71 \\
$2 \mathrm{~b}$ & $\mathrm{Me}$ & 200 & 174 & 78 \\
$3 \mathrm{~b}$ & $\mathrm{Et}$ & 200 & 185 & 86 \\
$4 \mathrm{~b}$ & $\mathrm{Ph}$ & 200 & 275 & 89 \\
\hline
\end{tabular}




\section{Results and discussion}

All the compounds were characterized by elemental analysis $(C, H, N, S)$, IR and $1 \mathrm{H}$ NMR spectroscopy.

\subsection{Elemental analysis}

Theorical values appear in brackets.

\begin{tabular}{cccccc}
\hline Compound & Molecular formula & $\% \mathrm{C}$ & $\% \mathrm{H}$ & $\% \mathrm{~N}$ & $\% \mathrm{~S}$ \\
\hline $1 \mathrm{a}$ & $\mathrm{C}_{10} \mathrm{H}_{13} \mathrm{~N}_{3} \mathrm{OS}$ & $51,7(53,8)$ & $5,9(5,9)$ & $18,1(18,8)$ & $17,7(14,4)$ \\
$2 \mathrm{a}$ & $\mathrm{C}_{11} \mathrm{H}_{15} \mathrm{~N}_{3} \mathrm{OS}$ & $55,6(55,7)$ & $6,6(6,4)$ & $17,5(17,7)$ & $13,4(13,5)$ \\
$3 \mathrm{a}$ & $\mathrm{C}_{12} \mathrm{H}_{17} \mathrm{~N}_{3} \mathrm{OS}$ & $57,4(57,3)$ & $6,8(6,8)$ & $16,7(16,7)$ & $13,0(12,8)$ \\
$4 \mathrm{a}$ & $\mathrm{C}_{16} \mathrm{H}_{13} \mathrm{~N}_{3} \mathrm{OS}$ & $64,0(64,2)$ & $5,9(5,7)$ & $14,1(14,0)$ & $10,6(10,7)$ \\
$1 \mathrm{~b}$ & $\mathrm{C}_{40} \mathrm{H}_{44} \mathrm{~N}_{12} \mathrm{O}_{4} \mathrm{Pd}_{4} \mathrm{~S}_{4}$ & $36,7(36,7)$ & $3,6(3,4)$ & $12,7(12,8)$ & $9,6(9,8)$ \\
$2 \mathrm{~b}$ & $\mathrm{C}_{44} \mathrm{H}_{52} \mathrm{~N}_{12} \mathrm{O}_{4} \mathrm{Pd}_{4} \mathrm{~S}_{4}$ & $38,6(38,7)$ & $3,9(3,8)$ & $12,0(12,3)$ & $9,0(9,4)$ \\
$3 b$ & $\mathrm{C}_{48} \mathrm{H}_{60} \mathrm{~N}_{12} \mathrm{O}_{4} \mathrm{Pd}_{4} \mathrm{~S}_{4}$ & $40,5(40,5)$ & $4,4(4,3)$ & $11,9(11,8)$ & $8,9(9,0)$ \\
$4 \mathrm{~b}$ & $\mathrm{C}_{64} \mathrm{H}_{60} \mathrm{~N}_{12} \mathrm{O}_{4} \mathrm{Pd}_{4} \mathrm{~S}_{4}$ & $38,3(47,6)$ & $3,2(3,7)$ & $8,1(10,4)$ & $6,4(7,9)$ \\
\hline
\end{tabular}

Chart 3. Elemental analysis characterization

The conclusion is that, with the exception of $\mathbf{4 b}$, the compounds are essentially pure.

\subsection{IR spectroscopy}

The IR spectra show that the $v(\mathrm{~N}-\mathrm{H})$ and $v(\mathrm{C}=\mathrm{S})$ stretches are absent in the cyclometallated compounds. This confirms that the deprotonation and the loss of $\mathrm{C}=\mathrm{S}$ double bond character is needed for the formation of the palladacycle.

\begin{tabular}{ccc|cc}
\hline Ligand & $v(\mathrm{~N}-\mathrm{H})$ & $v(\mathrm{C}=\mathrm{S})$ & Compound & $v(\mathrm{~N}-\mathrm{H})$ \\
\hline $1 \mathrm{a}$ & $3154 / 3243 / 3375$ & 826 & $1 \mathrm{~b}$ & $3159 / 3292$ \\
$2 \mathrm{a}$ & $3193 / 3366$ & 836 & $2 \mathrm{~b}$ & 3353 \\
$3 \mathrm{a}$ & $3201 / 3299$ & 829 & $3 \mathrm{~b}$ & 3341 \\
$4 \mathrm{a}$ & $3230 / 3296$ & 834 & $4 \mathrm{~b}$ & 3289 \\
\hline
\end{tabular}

Chart 4. IR spectroscopy characterization 


\section{3. ${ }^{1} H$ NMR spectroscopy}

The disappearance of the ortho aromatic proton resonance and the hydrazinic proton resonance ensures cyclometallation.

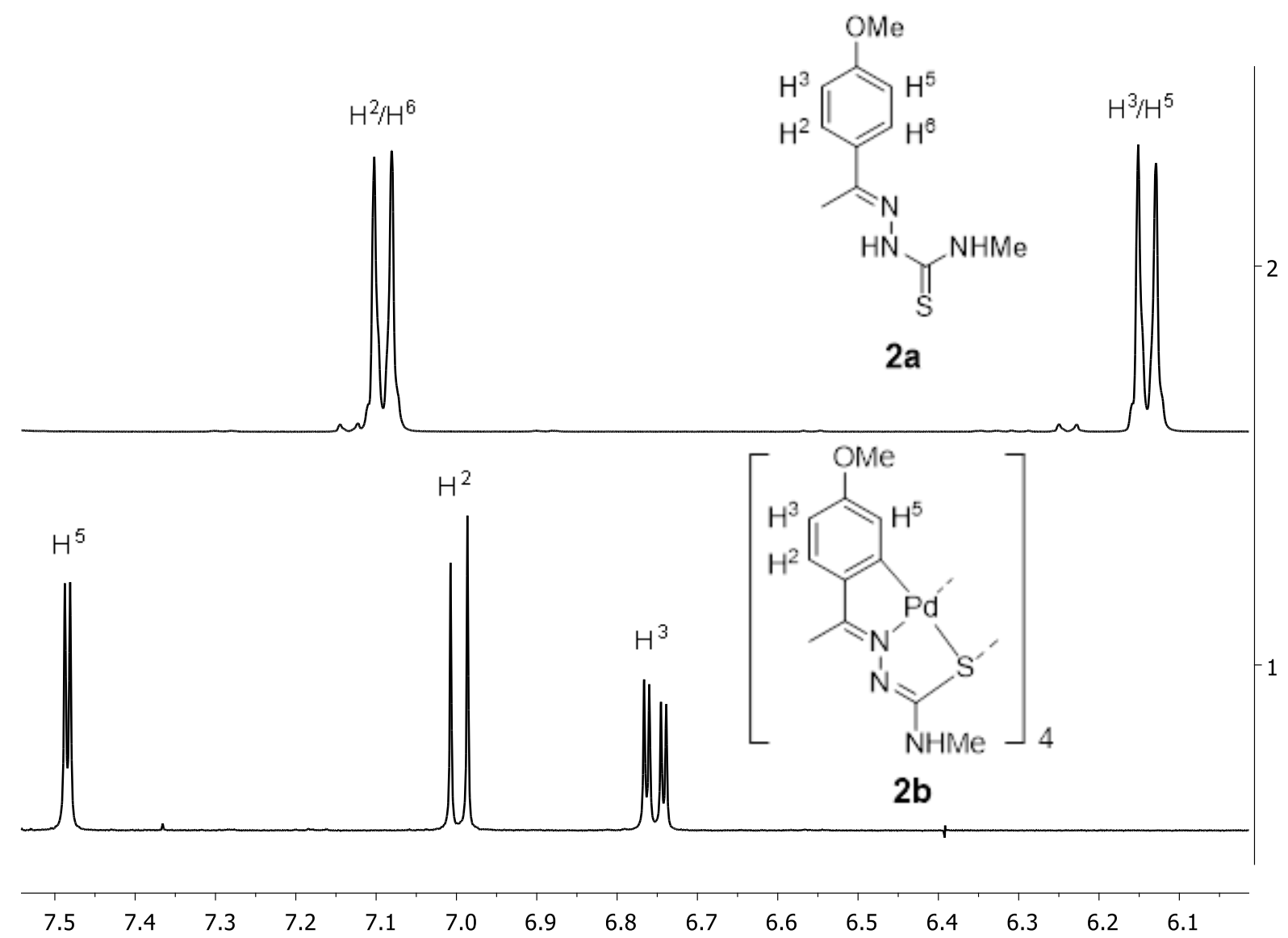

Figure 1. ${ }^{1} \mathrm{H}$ NMR stacked spectrum (400 MHz, DMSO-d $)$ for compounds $2 \mathrm{a}$ and $2 \mathrm{~b}$

\section{Conclusions}

- Coordination to the metal center occurs in the thiol form of the thiosemicarbazone, approved by IR spectroscopy.

- $\quad{ }^{1} \mathrm{H}$ NMR spectroscopy confirms cyclometallation, with the thiosemicarbazone ligand as tridentate $[C, N, S]$.

- The cyclometallated compounds show a tetranuclear structure, with two type of bonds between palladium and sulfur: Pd-Schelate and Pd-Sbridging.

- Elemental analysis confirms the purity of the compounds, except for $\mathbf{4 b}$.

Funding: "Francisco Reigosa wants to thank the financial support to the Spanish Government (AEI) through an FPU grant (number 13/05014)"

Acknowledgments: The authors thank funding from Xunta de Galicia (Galicia, Spain) under the Grupos de Referencia program (GRC 2019/014)

Conflicts of Interest: "The authors declare no conflict of interest" 


\section{References}

1. Trofimenko, S., Inorg. Chem., 1973, 12, 1215. (DOI: 10.1021/ic50124a001)

2. Antelo, J. M., Compuestos ciclometalados Homo- y Heterodinucleares de Metales de Transición, Ph. D. Thesis, University of Santiago de Compostela, Santiago de Compostela, 2009.

3. Yan, H.; Chellan, P.; Li, T.; Mao, J.; Chibale, K.; Smith, G. S., Tetrahedron Lett., 2013, 54, 154. (DOI: 10.1016/j.tetlet.2012.10.115)

4. Prabhu, R. N.; Ramesh, R., Tetrahedron Lett., 2012, 53, 5961. (DOI: 10.1016/j.tetlet.2012.08.120)

5. Ibrahim, A. A.; Khaledi, H.; Hassandarvish, P.; Mohd Ali, H.; Karimian, H., Dalton Transactions, 2014, 43, 3850. (DOI: 10.1039/C3DT53032A)

6. Kalaivani, P.; Prabhakaran, R.; Dallemer, F.; Poornima, P.; Vaishnavi, E.; Ramachandran, E.; Padma, V. V.; Renganathan, R.; Natarajan, K., Metallomics, 2012, 4, 101. (DOI: 10.1039/C1MT00144B)

7. Budzisz, E.; Bobka, R.; Hauss, A.; Roedel, J. N.; Wirth, S.; Lorenz, I. P.; Rozalska, B.; Wieckowska-Szakiel, M.; Krajewska, U.; Rozalski, M., Dalton Transactions, 2012, 41, 5925. (DOI: 10.1039/C2DT12107G)

(C) 2019 by the authors. Submitted for possible open access publication under the terms and conditions of the Creative Commons Attribution (CC BY) license (http://creativecommons.org/licenses/by/4.0/). 